\title{
A STUDY OF LISTENING COMPREHENSION PROBLEMS ENCOUNTERED BY THE THIRD SEMESTER STUDENTS AT STMIK PRABUMULIH
}

\author{
Hepnyi Samosir ${ }^{1}$ \\ ${ }^{1}$ STMIK Prabumulih \\ Email: hepnis@yahoo.com
}

\begin{abstract}
Even though listening is often categorized as a passive activity, it is not a simple process as it may seem. There is an active process in it because listeners must focus on the spoken language and actively draw what message is being delivered. There are some factors that make a listener may need a lot of work to comprehend a spoken language such as colloquialism, accent, intonation, hesitation, word or phrase clusters, and content. Preliminary data gained from pre-observation at STMIK Prabumulih showed that the third semester students found themselves hard to acquire information from spoken language, hence it is necessary to find out the causes so that make an effort to develop their listening skills. The method used was descriptive research design. The result revealed that students encounter various kinds of listening problems in learning comprehension such as unfamiliar words, the length of the spoken text, speed rate, lack of concentration and pronunciation, and the noises around come from both the background sound of the spoken language recording and environmental sound such as sound from outside classroom.
\end{abstract}

Keywords: listening; comprehension; listening comprehension problems; descriptive

\section{INTRODUCTION}

The importance of listening skills is undeniable. People follow a conversation by receiving language inputs. The activity of receiving does not mean that there is no active process while listening. It is not only hearing what is being spoken but also understanding the words and relate to them. It encompasses the multiple processes involved in understanding spoken language. In grasping the meaning, a listener must recognize the speaker's accent, pronunciation, word or phrase.

Briefly compared to reading which is the other receptive skill, they are different in the way the message is processed. While readers can go back to the text every time they want, listeners have no opportunity of going back to the section they might miss. Unlike reading, listening needs to process the spoken language instantly. Although reading and listening occur in different modalities, the underlying cognitive tasks required for their performance involve some 
of the same processes: comprehending an incoming stream of information, integrating this information online, constructing a mental representation of the syntactic structure and semantic content (i.e., meaning), resolving any ambiguities or overcoming interference from conflicting representations, etc (Bloomfieldet al., 2010).

Numerous previous studies on the listening the problem revealed that most students encountered problem in listening to the spoken language. Hamauda (2013) investigated the listening comprehension problems encountered by Saudi students in the EL listening classroom. He found out that accent, pronunciation, speed of speech, insufficient vocabulary, different accent of speakers, lack of concentration, anxiety, and bad quality of recording were the major listening comprehension problems encountered by EFL Saudi learners. Furthermore, it was emphasized that EFL learners had crucial problems in listening comprehension because universities paid attention to grammar, reading, and vocabulary.

The case study conducted by Ismail (2015) also revealed that although the students were aware of the importance of the listening skill, they found comprehension difficult, and this was due to the insufficient training in the high school, and the content of the listening text.

Preliminary data gained from pre-observation at STMIK Prabumulih revealed that the students found hard to acquire information from spoken language, hence it is necessary to find out the causes so that make an effort to develop their listening skill as Bingol, et al (2014) conclude that teachers should teach the students appropriate listening strategies. There is no an ideal method that fits all kinds of classes. But we should find our students' limit, diagnose their capacity, and find out the factors that may influence their listening comprehension. Then we may offer them to complete different type of activities. Listening tasks should involve progress from fundamental to more complex as the student obtains in language ability.

\section{METHOD}

The method used was descriptive research design. Data were collected from the questionnaires distributed to 58 third semester students of Information System at STMIK Prabumulih. The questionnaire was designed to gain the target information based on the objective of the study. The questionnaire referred to Hamouda (2013) about factors that influence listening comprehension.

\section{FINDINGS AND DISCUSSION}

\subsection{Students' Perception of the Importance of Listening Skills}


The first section of the questionnaire was set to find out the students' perception of the importance of listening skills consisted of six statements. The first statement was aimed at getting the information of their awareness of the perceived importance of English listening skill. The majority of the students (62.07\%) were always aware of the perceived importance of English listening skill. No student perceived it unimportant. But when asked about the difficulty of listening comprehension, $44.83 \%$ of the students remarked that listening comprehension was difficult. Only $1.72 \%$ vote it was not difficult.

Without a doubt, the students agreed that listening skill had a great effect in communicating with people. It was a necessary skill to connect to another person and grasp the information from spoken language. However, they strongly stated that listening skill was hard to acquire. They admitted that they could easily become frustrated when trying to get engaged in listening.

During the process of listening comprehension, various factors may affect their listening ability as Graham (2006) avows that restricted vocabulary, poor grammar, and misinterpretations about listening task increase learners' listening comprehension problems. Buck (2001) lists difficulties which a listener may deal with during the listening activity, such as unknown vocabularies, unfamiliar topics, fast speech rate, and unfamiliar accents. Bingol et al (2014) analyze some potential problems may appear during listening. The problems include quality of recorded material, cultural differences, accent, unfamiliar vocabulary, length and speed of the listening, physical conditions, and lack of concentration. However, Goh (2000) asserts that the most common problem is "quickly forget what is heard (parsing)."

Interestingly, they found that listening comprehension was exciting (34.48\% always, and $53.45 \%$ sometimes). There was only $6.90 \%$ stated that listening comprehension was boring and not interesting. They found that listening was exciting. It was not boring. Being aware of the importance of listening skill as well as finding listening exciting and not boring, it is necessary to motivate them, prepare interesting listening materials to deliver, and frequently train them so that they receive sufficient training in listening comprehension.

As a matter of fact, $56.55 \%$ never received sufficient training in English listening comprehension during their school and tertiary stage. This led them (51.72\%) to be not familiar with listening strategies which could help them to comprehend spoken language. This was resulted from a number of reasons. Suyono (2010) argues that scarce materials for listening are always the most often cited reason for the deficiency. Comprehension based teaching which generally emphasizes product rather than process is another factor that may inhibit students' 
development of listening skills, and an evaluation system which favors multiple choice comprehension tests is believed to also complicate the problem as well.

\subsection{Listening Problem Related to the Message of the Listening Text}

The first and second questions were asked to know whether unfamiliar words, including jargon and idioms, and complex grammar interfere with the learners' listening comprehension. The great majority of the students (43.10\% often and $32.76 \%$ always) agreed that unfamiliar words interfered with their listening comprehension. In listening to a spoken language, students must deal with vocabulary. Students tend to stop listening and think about the meaning of an unknown word which can make them miss the next part of the speech (Gilakjani \& Sabouri, 2016). Nation (2001) argues that listeners must have an adequate vocabulary to understand a passage in another language. But when listening, there might be words including jargon and idiom unfamiliar to them, hence they could not correctly grasp the information.

They also agreed that listening to an informal spoken language was more difficult than listening to a formal one. The informal spoken language consisted of a lot of words unfamiliar to students. Collocation was also found difficult to grasp. Vocabulary and grammar also tend to be far more colloquial and much less formal (Osada, 2004). Lewis (2000) stresses that teachers need to raise students' awareness of collocations and to initiate their own action research to make sure the changes they make are of benefit tostudents. Students should also be told that flexibility and adjustment occur frequently to form collocations and hence changes in pronunciation take place with no pauses between words, less important sounds shortened or eliminated altogether (Chen \& Cheng, 2007).

Complex grammatical structures also always interfered with the students' listening comprehension (13.79\% never, $27.59 \%$ sometimes, $24.14 \%$ often, and $34.48 \%$ ). Grammar was one of the potential obstacles for students in listening comprehension (Hasan, 2000; Graham et al., 2008; Osada, 2004). According to Bloomfield, et al (2010) different types of spoken passages have different structure, which can make them easier or more difficult for L2 listeners to understand. It is obvious that comprehension is much more difficult to grasp if students do not know how words come together.

A long spoken language also interfered with the students' listening comprehension (50.00\% always). They found it needed a lot of work to interpret the meaning of a long spoken language. It made them feel under pressure, and difficult to follow the sequence of the spoken language, and even lost their concentration (1.72\% never, $17.24 \%$ sometimes, $27.59 \%$, and $53.45 \%)$. The length of time students listen may cause memory problems or even fatigue and 
this would distract listeners' attention from grasping the meaning of the text, and learners may miss the rest of the text when there is a lapse in concentration. This may be attributed to the short memory span for the target language (Hasan, 2000).

Bloomfield, et al (2010) define passage length with a number of measures, including syllables/second, duration (in minutes or seconds), and number of words or sentences. Even they state that there is also reason to predict that longer passages will have a greater impact on the listening comprehension of lower proficiency listeners but the result showed that $50 \%$ students could not maintain concentration if the text was long. It was not easy to concentrate when listening as Osada (2004) argues that even the shortest break in attention can seriously impair comprehension. Concentration is easier when students find the topic of the listening passage interesting; however, students sometimes feel listening is very tiring even if they are interested because it requires an enormous amount of effort to follow the meaning.

The findings also revealed that the students could not concentrate because they both searched for the answers and listen to the dialogue at the same time $(5.17 \%$ never, $18.97 \%$ sometimes, $32.76 \%$ often, $43.10 \%$ always). They also lost their concentration when they thought what new words meant $(0.00 \%$ never, $31.03 \%$ sometimes, $36.21 \%$ often, $32.76 \%$ always). $50.00 \%$ of the students tended to try to understand every single word of incoming speech. They might miss the next spoken language because they spent a lot of time thinking about the meaning.

They also found it difficult to understand spoken language when the topic was unfamiliar and uninteresting. There were $48.28 \%$ of the students always encountered problem with these items. According to Bingol, et al (2014) when students find the topic of the listening text interesting, comprehending would be easier.

To overcome the problem pertinent to the message, the followings are some suggestions that expected to be useful:

1. prepare listening materials that fit the students' level and need from the very simple texts to the lower level students and moved to the very complicated authentic materials to the advanced students (Hamauda, 2013; Bingol, M.A, et al., 2014; Gilakjani \& Sabouri, 2016),

2. provide authentic materials rather than created that help understand better the natural speech (Bloomfoeld, et al, 2010;Gilakjani \& Sabouri, 2016),

3. design task-oriented exercises that arouse the students' interest and help them learn listening skills subconsciously (Bingol et al., 2014; Gilakjani \& Sabouri, 2016), 
4. motivate students to use various types of listening strategies (Hamauda, 2013; Gilakjani \& Sabouri, 2016)

5. accommodate students with different kinds of input, such as lectures, radio news, films, TV plays, announcements, everyday conversation, interviews, storytelling, English songs, and so on (Hamauda, 2013; Gilakjani \& Sabouri, 2016),

6. find visual aids or draw pictures and diagrams associated with the listening topics to help students guess or imagine actively (Hamauda, 2013),

7. provide students with background knowledge and linguistic knowledge while listening to different listening materials (Hamauda, 2013; Gilakjani \& Sabouri, 2016).

\subsection{Listening Problems Related to the Listener}

The first question to find out what listening problems related to the listener was whether they found difficult to get a general understanding of the spoken text from the first listening. The result was only $1.72 \%$ never found difficult. It meant that almost all the students found difficult to get a general understanding of the spoken text from the first listening. They also preferred short answer question to WH questions (67.24\% sometimes, and $20.69 \%$ often). Related to words or phrases, $46.55 \%$ always found it difficult to memorize them.

Another finding was the majority of the students (39.66\% often, $39.66 \%$ always) found difficult to recognize the words when listening but when the words were transcribed, the students found that they were familiar with. Students might be familiar with certain words when reading. In contrast, they were not able to recognize the words when listening. Some word also might be similarly spelled and pronounced to one another such as I thought about it and I taught about it. The word thought in the first sentence is the past tense of think, and the word in the second one is the past tense of teach. This kind of similar spelled and pronounced words might be easily misunderstood.

Related to those findings, it demands to provide background knowledge and linguistic knowledge, to set the purpose of listening whether it is a general or specific information, and to guide the students to respond the spoken (Bloomfield, 2010; Lynch, 2005). What all this boils down to is that sometimes pronunciation work is the most important part of listening comprehension skills building (Case:2019).

\subsection{Listening Problems Related to the Speaker}

Finding revealed that accent did not affect much the students' listening. This was because during three semesters having English subject, they were exposed to American standard only. It has not been considered yet to expose them to other accents. The problem was if the 
speaker spoke too fast. $84.48 \%$ of the students found it difficult to grasp the information. Lynch (2005) suggests taking into account how quickly the speakers speak; whether the pace of the speaker allows sufficient "time" for mental processing of the speech by the listener, and whether the language of the speaker flows at a faster or slower rate than the listener is accustomed to.

Regarding the difficulty pertinent to the spoken language rate, Osada (2004) states that listeners cannot control the speed of delivery but they should try to notice the rate and the intonation as Berman (2003)states that pace is the speed of speech. Unimportant points or small details are usually spoken more quickly. Important points, such as main ideas, are usually spoken more slowly and clearly. Hamauda (2013) suggests that teachers inform their students about connected speech which is characterized by weak forms, contractions, elision, and assimilation any time convenient so that the students do not feel stressful and surprised when they listen to authentic listening materials.

Finding also revealed that the students found it was difficult to understand the natural speech which was full of hesitation and pauses. Buck (2001) argues that hesitation phenomena can present a major comprehension difficulty to non-native speakers who are listening to spontaneous speech. Hesitations such as unfilled and filled pauses, repetition, and false start may become an obstacle to listening comprehension. Hesitations and pauses in spontaneous speech cause perceptual problems and comprehension errors for non-native speakers (Hasan, 2000).

Taking into account the problem of hesitations may affect comprehension, Buck (2001) asserts that hesitation that slow down the speech rate do aid comprehension for L2 listeners but it is necessary for the listeners to recognize the fillers. Harmer (2001) suggests that the teacher train students to understand what is being said in such conversations: to get them to disregard redundancy, hesitation, ungrammaticality and to be conscious of the speakers' changing their minds.

\subsection{Listening Problems Related to the Physical Settings}

Both noises around and unclear sound commonly interrupt the students during the listening process. It is not remarkably. Even listening to his/her native language, everyone may make a very great effort in order to grasp the message delivered due to the noises and unclear sound. Field (2003) argues that all spoken language is distorted because of the phonological processes such as reduction, assimilation, elision, resyllabification, and cliticization, among others. Moreover, recordings from telephone calls, conversations, or radio transmissions are often distorted or mixed with background noise (Bloomfield, et al., 2010). 
Regarding problem found related to the physical setting, it is crucial to use well recorded, and clear spoken text with limited noise around because the result revealed that the majority of the students $(75.86 \%)$ voted they could not focus on the text with noises around. The noises around might come from both the background sound of the spoken language recording and environmental sounds such as sound from outside classroom and sliding door, hence it is also necessary to prevent the noise coming in from outside.

\section{CONCLUSION}

To sum up, the students of STMIK Prabumulih agreed that listening skill was very important. However, they perceived it to be difficult. Findings revealed some factors that affect their listening skill. When listening they tended to try to work out what every single word mean, and even spent a lot of time thinking about the meaning of unfamiliar words, hence they might miss the next message. It is necessary to show the students how to recognize the important words that build the spoken language up. They also might not recognize the word that they were familiar with when reading. The unfamiliar and uninteresting topic also encountered problem with their listening. When students listened to an unfamiliar and uninteresting topic, they might get tired. The speed would be a problem when the speaker spoke too fast that students needed to try to notice the rate and the intonation. Natural speech which was full of hesitation and pauses presented a difficulty to them. Noises around also put them off their stride.

\section{REFERENCES}

Berman, M. (2003). Listening strategy guide. Dyed International Inc. Retrieved from: http://202.197.120.98/Downloads/LrnStrtg/str_002.pdf.

Bingol, M.A, et al. (2014). Listening comprehension difficulties encountered by students in second language learning class. Journal of Educational and Instructional Studies in the World 4(4), 1-6. Retrieved from: http://www.wjeis.org/FileUpload/ds217232/File/01b.bingol.pdf6

Bloomfield, A. et al. (2010). What makes listening difficult? Factors affecting second language listening comprehension. Retrieved from: https://www.casl.umd.edu/wpcontent/uploads/2016/02/WHAT-MAKES-LISTENING-DIFFICULT-tech-details2011.pdf.

Buck, G. (2001). Assessing listening. Cambridge: University Press. 
Case. A. (2019)._Why your students have problems with listening comprehension. Retrieved from: $\quad$ https://www.usingenglish.com/articles/why-your-students-have-problems-withlistening-comprehension.html

Chen, H.M \& Cheng, S.H. (2007). An investigation on the listening difficulties of Technical College students in Taiwan. Journal of China Institute of Technology 36(6), Vol.362007.6.

Field, J. (2003). Promoting perception: Lexical Segmentation in L2 listening. ELT Journal, 57(4), 325-334. $\quad$ Retrieved from: http://peterstrutt.co.uk/wpcontent/uploads/2015/12/Perception_in_listening.pdf.

Gilakjani, A.P \& Ahmadi, M.R. (2011). A study of factors affecting EFL learners' English listening comprehension and the strategies for improvement. Journal of Language Teaching and Research, 2(5), 977-988.

Goh, C. (2000). A cognitive perspective on language learners' listening comprehension problems. System, 28(1), 55-75.

Graham, S. (2006). Listening Comprehension: The Learners' Perspective. System, 34, 165-182. http://dx.doi.org/10.1016/j.system.2005.11.001

Graham, Set al (2008). Listening comprehension and strategy use: a longitudinal exploration. System, 36, 52-68. http://dx.doi.org/10.1016/j.system.2007.11.001

Hamouda, A. (2013). An investigation of listening comprehension problems encountered by Saudi students in the EL listening classroom. International Journal of Academic Research in Progressive Education and Development, 2(2), 133-155. Retrieved from: http://hrmars.com/admin/pics/1882.pdf

Harmer, J. (2001). The practice of English language teaching, $3^{\text {rd }}$ ed: England: Pearson Education.

Hasan, A.S. (2000). Learners' Perceptions of Listening Comprehension Problems.

Language,Culture and Curriculum, 13, 137-152. Retrieved from: https://www.tandfonline.com/doi/abs/10.1080/07908310008666595

Ismail, K. (2015). An Investigation of listening problems encountered by EFL learners a case study of second year license of English at UKMO (Thesis, Kasdi Merbah University-Ouargla), Retrieved from: https://bu.univuargla.dz/master/pdf/KAZOUZ_Ismail.pdf 
Lewis, M. (2000). Language in the lexical approach. In M. Lewis (Ed.), Teaching collocation: further developments in the lexical approach. (pp. 133-134). London: Language Teaching Publications.

Lynch, L.M. (2005). Learning a language: what makes listening difficult?. Retrieved from: http://ezinearticles.com/?Learning-a-Language:-What-Makes-ListeningDifficult?\&id=96094.

Nation, I. S. P. (2001). Learning vocabulary in another language. England: Cambridge University Press.

Osada, N.(2004). Listening comprehension research: a brief review of the last thirty years. Dialogue, 3, 53-66. $\quad 3$ Retrieved from https://pdfs.semanticscholar.org/6d58/c7a45da8c9e74cf4f0dfa0ea928b1a6923a1.pdf

Suyono. (2010). Raising awareness of learning strategy in listening for tertiary EFL learners. Ta'dib, 13(2), 122-133. Retrieved from: ecampus.iainbatusangkar.ac.id/ojs/index.php/takdib/.../183 